\title{
Modulation of Immunological Responses by Aqueous Extract of Datura Stramonium L. Seeds on Cyclophosphamide-Induced Immunosuppression in Wistar Rats
}

Parker Elijah Joshua

University of Nigeria

Yahaya Junaidu

University of Nigeria

Daniel Emmanuel Ekpo ( $\square$ ekpodaniele@gmail.com )

University of Nigeria

Joyce Oloaigbe Ogidigo

University of Nigeria

Arome Solomon Odiba

University of Nigeria

Rita Onyekachukwu Asomadu

University of Nigeria

Samson Ayodeji Oka

Kogi State University

Olasupo Stephen Adeniyi

Benue State University

\section{Research Article}

Keywords: Medicinal plants, Datura stramonium L., immune system, immunosuppression, immunoglobulins, cyclophosphamide, Wistar rats.

Posted Date: July 27th, 2021

DOI: https://doi.org/10.21203/rs.3.rs-738146/v1

License: (c) (1) This work is licensed under a Creative Commons Attribution 4.0 International License.

Read Full License 


\section{Abstract}

Background: Datura stramonium L. (Solanaceae) is used traditionally in West Africa to treat asthma, epilepsy, rheumatoid arthritis, filariasis microbial infections and conjunctivitis. This study investigated the immunomodulatory effects of aqueous seed extract of $D$. stramonium L. (ASEDS) on Wistar rats.

Methods: Following phytochemical analysis of ASEDS and acute toxicity study, thirty Wistar rats of both sexes $(180-200 \mathrm{~g})$ were randomized into 6 groups $(n=5)$. Rats in groups 1,2 and 3 served as normal, negative and standard controls respectively. Immunosuppression was induced using Cyclophosphamide, $10 \mathrm{mg} / \mathrm{kg}$ body weight (b.w.) orally for 27 days. Group 2 rats were untreated while Groups 3-6 rats received $5 \mathrm{mg} / \mathrm{kg}$ b.w. Levamisole, 60,90 and $120 \mathrm{mg} / \mathrm{kg}$ b.w. ASEDS orally for 28 days respectively. The effects of ASEDS on immune cells, immunoglobulins $A, G$ and $M$ levels, lipoproteins, and antioxidant status of immunosuppressed rats were evaluated.

Results: ASEDS indicated $\mathrm{LD}_{50}$ above $5000 \mathrm{mg} / \mathrm{kg}$ b.w. with moderate contents of carbohydrates, glycosides, saponins, tannins, terpenoids, and high contents of alkaloids, flavonoids and phenols. Cyclophosphamide triggered significant $(p<0.05)$ reduction in total leucocyte count and differentials, IgA, IgG, high-density lipoproteins (HDL), catalase, superoxide dismutase, glutathione peroxidase, vitamins $A$, $C$ and $E$ levels of the negative control rats. Treatment with ASEDS led to significant $(p<0.05)$ increases in immune cell counts, immunoglobulin synthesis, HDL levels, and antioxidant status of the test groups.

Conclusions: The findings demonstrate the immunomodulatory benefits of ASEDS and its potential in the development of potent immunomodulatory drugs.

\section{Background}

Immunosuppression is a reduction in the capacity of immune system to respond effectively to antigens including surface antigens on tumor cells. It can occur as a result of chronic infections, accumulation of toxic chemicals in the body and exposure to high doses of radiations [1]. According to Hutchinoson and Geissler [2] immunosuppression has been adopted deliberately as a means of treating autoimmune diseases and preventing acute graft rejection. Despite these benefits, prolonged immunosuppression would lead to infections, bone marrow suppression, cancer and infertility [3]. Cyclophosphamide is one of the potent immunosuppressive drugs belonging to the group known as oxazaphosporine [4], and has been widely investigated for its immunomodulatory effects [5]. The drug when ingested undergoes extensive metabolism in the liver via the cytochrome P-450 and produces phosphoramide as its active metabolite. Phosphoramide is an alkylating agent which inhibits DNA replication by irreversibly interacting with it at number seven atom of guanine base. This interaction causes cell death among resting and dividing leucocytes and thus leads to impair humoral and cellular immune responses [6].

Medicinal plants are known to have great potential for treatment and management of certain diseases including those affecting different components of the immune system [7]. One of such plant is Datura Stramonium L. (Solanaceae) (Fig. 1). It is an annual plant that is native to Asia and Africa [8]. In Nigeria 
especially in Kogi State, it is found growing in abandoned farmlands and dumpsites. It is popularly known for its narcotic effect as a result called names such as Devil's apple, Angel's trumpet and Jimson weed but its indigenous names include Jegemi in Igala, Myaramwo in Igbo, Gegemu in Yoruba and Zakami in Hausa tribes of Nigeria. It is used traditionally to treat asthma, epilepsy, rheumatoid arthritis, filariasis and as antimicrobials, notably against Staphylococcus aureus, Aspergillus niger and conjunctival virus [9].

Rapid advances in human civilization have led to the increasing presence of various synthetic chemicals in the environment. Some of these chemicals and their products are immunotoxins which are capable of rendering hosts more susceptible to infectious diseases as a result of immunosuppression [10].

According to the World Health Organization (WHO), most antibiotics would lose their antimicrobial action by the year, 2020 [11]. Consequently, immunomodulation becomes a reliable alternative in the treatment of diseases particularly those that are immune-mediated since its mechanism can enhance both specific and non-specific immunities [12]. Immuno-modulators are substances that can either enhance or suppress any component of immune system. Examples of immuno-modulators include adjuvants, vitamins, cytokines and herbs. Jantan et al. [13] defined natural immuno-modulators as natural products of herbal origin called phytochemicals. Therefore, plant-derived substances can be used to modulate an immunosuppressed system and these substances could be present in the extract of $D$. stramonium seeds. This necessitated the study.

\section{Results}

\section{Percentage yield of ASEDS}

Aqueous crude extraction of $257.6 \mathrm{~g}$ of powdered D. stramonium L. seeds yielded $20.35 \mathrm{~g}$ of ASEDS, representing $7.9 \%$ of the total quantity of the powdered plant material extracted.

\section{Phytochemical composition of ASEDS}

Qualitative phytochemical screening of ASEDS indicated high content of phenols, alkaloids, and flavonoids, with moderate contents of glycosides, terpenoids and carbohydrates, whereas saponins, tannins and steroids were present in lower quantities Table 1.

\section{Acute toxicity $\left(L_{50}\right)$ study of ASEDS}

Acute toxicity study indicated that ASEDS did not cause any form of toxicity when administered up to a dose of $5000 \mathrm{mg} / \mathrm{kg}$ b.w No death, changes morphological and/or behavioral patterns of the tested mice was observed. Also, no significant $(p>0.05)$ changes in body weight of the tested mice in Phases I and II of the study $24 \mathrm{~h}$ post-ASEDS treatment was recorded (Table 2).

Table 1 Phytochemical composition of ASEDS 


\begin{tabular}{|lll|}
\hline Phytochemicals & $\begin{array}{l}\text { Qualitative analysis } \\
\text { (Bioavailability) }\end{array}$ & $\begin{array}{l}\text { Quantitative analysis } \\
(\mathrm{mg} / \mathrm{g})\end{array}$ \\
\hline Alkaloids & +++ & $269.05 \pm 1.63$ \\
\hline Carbohydrates & ++ & $52.59 \pm 0.59$ \\
\hline Flavonoids & +++ & $278.65 \pm 0.63$ \\
\hline Phenols & +++ & $396.06 \pm 6.56$ \\
\hline Glycosides & ++ & $148.71 \pm 1.83$ \\
\hline Saponins & + & $0.76 \pm 0.07$ \\
\hline Steroids & + & $2.06 \pm 0.10$ \\
\hline Tannins & + & $0.03 \pm 0.00$ \\
\hline Terpenoids & ++ & $72.04 \pm 21.08$ \\
\hline
\end{tabular}

Results are expressed as mean \pm standard deviation, $\mathrm{n}=3$. Highly present $(+++)$, moderately present $(++)$, scanty $(+)$.

Table 2 The acute toxicity $\left(\mathrm{LD}_{50}\right)$ profile of ASEDS

\begin{tabular}{|llllll|}
\hline Groups & $\begin{array}{l}\text { Dosage } \\
(\mathrm{mg} / \mathrm{kg} \mathrm{b} . w)\end{array}$ & Mortality & $\begin{array}{l}\text { Behavioral } \\
\text { Changes }\end{array}$ & $\begin{array}{l}\text { Body weight }(\mathrm{g}) \\
\text { Pre-treatment }\end{array}$ & Post-treatment \\
\hline Phase 1 & & & & & \\
Group 1 & 10 & $0 / 3$ & Nil & $24.69 \pm 0.42^{\mathrm{a}}$ & $25.86 \pm 0.44^{\mathrm{a}}$ \\
\hline Group 2 & 100 & $0 / 3$ & $\mathrm{Nil}$ & $26.82 \pm 0.53^{\mathrm{b}}$ & $27.98 \pm 0.34^{\mathrm{b}}$ \\
\hline Group 3 & 1000 & $0 / 3$ & $\mathrm{Nil}$ & $26.64 \pm 0.19^{\mathrm{b}}$ & $27.03 \pm 0.13^{\mathrm{b}}$ \\
\hline Phase 2 & & & & & \\
\hline Group 1 & 1600 & $0 / 3$ & $\mathrm{Nil}$ & $27.37 \pm 0.21^{\mathrm{c}}$ & $27.89 \pm 0.26^{\mathrm{c}}$ \\
\hline Group 2 & 2900 & $0 / 3$ & $\mathrm{Nil}$ & $28.24 \pm 0.59^{\mathrm{d}}$ & $28.75 \pm 0.71^{\mathrm{d}}$ \\
\hline Group 3 & 5000 & $0 / 3$ & $\mathrm{Nil}$ & $28.84 \pm 1.47^{\mathrm{d}}$ & $28.99 \pm 1.21^{\mathrm{d}}$ \\
\hline
\end{tabular}

Results are expressed as mean \pm standard deviation $(n=3)$; mean values with same lowercase alphabets as superscripts for each group when compared across the pre- and post-treatment rows are not significantly different at $p<0.05$. 
Table 3 shows the Total leucocyte count of the Negative control (group 2) to be significantly $(p<0.05)$ lower when compared to normal control and ASEDS treated groups. The normal control rats recorded significantly $(p<0.05)$ higher lymphocyte counts when compared to the negative control and the treated groups. Dose-dependent increases in leucocytes and lymphocytes count were observed in the ASEDS treat groups. We also observed a significant $(p<0.05)$ increase in neutrophils for the negative control relative to the normal control and the treated groups respectively. Immunosuppression also led to significant $(p<0.05)$ declines in monocytes and eosinophils of the negative control when compared to the normal control. Treatment with ASEDS and standard drug (Levamisole) improved the levels of monocytes and eosinophils in the test groups. Basophils where not present in the negative control rat group following cyclophosphamide pretreatment. However, treatment with ASEDS and Levamisole triggered significant $(p<0.05)$ increase in basophil count of the test groups.

Table 3 Effect of ASEDS on immune cells of cyclophosphamide-induced immunosuppression in rats

$$
\begin{array}{cl}
\text { Groups } & \text { Total Leukocyte } \\
\text { Count }\left(\times 10^{9} / \mathrm{L}\right) & \text { Differential cell count }(\%)
\end{array}
$$

\begin{tabular}{|c|c|c|c|c|c|c|}
\hline & & $\begin{array}{l}\text { Lymphocytes } \\
\text { (\%) }\end{array}$ & $\begin{array}{l}\text { Neutrophils } \\
\text { (\%) }\end{array}$ & $\begin{array}{l}\text { Monocytes } \\
\text { (\%) }\end{array}$ & $\begin{array}{l}\text { Eosinophils } \\
\text { (\%) }\end{array}$ & $\begin{array}{l}\text { Basophils } \\
\text { (\%) }\end{array}$ \\
\hline 1 & $9.98 \pm 1.05^{a}$ & $\begin{array}{l}75.88 \pm 1.94 \\
a\end{array}$ & $\begin{array}{l}18.02 \pm \\
1.00^{a}\end{array}$ & $\begin{array}{l}3.38 \pm \\
1.87^{a}\end{array}$ & $\begin{array}{l}2.12 \pm 0.87 \\
a\end{array}$ & $\begin{array}{l}0.60 \pm \\
0.54^{a}\end{array}$ \\
\hline 2 & $2.30 \pm 1.05^{b}$ & $\begin{array}{l}61.60 \pm 3.78 \\
b\end{array}$ & $\begin{array}{l}34.00 \pm \\
3.39 \mathrm{~b}\end{array}$ & $\begin{array}{l}2.20 \pm \\
0.83^{b}\end{array}$ & $\begin{array}{l}2.20 \pm 0.83 \\
a\end{array}$ & $\begin{array}{l}0.00 \pm \\
0.00^{a}\end{array}$ \\
\hline 3 & $9.90 \pm 1.56^{a}$ & $\begin{array}{l}31.60 \pm 2.83 \\
c\end{array}$ & $\begin{array}{l}31.40 \pm \\
1.14 \mathrm{~b}, \mathrm{c}\end{array}$ & $\begin{array}{l}13.40 \pm \\
1.14^{c}\end{array}$ & $\begin{array}{l}22.80^{\mathrm{E}} \\
2.68^{\mathrm{b}}\end{array}$ & $\begin{array}{l}1.40 \pm \\
0.54^{b}\end{array}$ \\
\hline 4 & $16.12 \pm 0.53^{c}$ & $\begin{array}{l}29.20 \pm 4.81 \\
c\end{array}$ & $\begin{array}{l}57.20 \pm \\
2.65^{d}\end{array}$ & $\begin{array}{l}9.60 \pm \\
2.60^{d}\end{array}$ & $\begin{array}{l}2.40 \pm 1.14 \\
\mathrm{a}\end{array}$ & $\begin{array}{l}1.00 \pm \\
1.00^{\mathrm{b}}\end{array}$ \\
\hline 5 & $18.74 \pm 2.75^{c, d}$ & $\begin{array}{l}38.00 \pm 6.20 \\
d\end{array}$ & $\begin{array}{l}39.20 \pm \\
0.83 \mathrm{e}^{-}\end{array}$ & $\begin{array}{l}8.48 \pm \\
0.50 d\end{array}$ & $\begin{array}{l}2.36 \pm 1.46 \\
a\end{array}$ & $\begin{array}{l}0.40 \pm \\
0.89^{c}\end{array}$ \\
\hline 6 & $21.40 \pm 1.95^{d}$ & $\begin{array}{l}55.86 \pm 2.89 \\
e\end{array}$ & $\begin{array}{l}28.86 \pm \\
5.09^{c}\end{array}$ & $\begin{array}{l}17.04 \pm \\
22.91^{\mathrm{e}}\end{array}$ & $\begin{array}{l}7.24 \pm 2.83 \\
d\end{array}$ & $\begin{array}{l}1.00 \pm \\
0.00^{b}\end{array}$ \\
\hline
\end{tabular}

Results are expressed as mean \pm standard deviation, $\mathrm{n}=5$. Mean values with different lowercase alphabets as superscripts when compared down the groups are significantly different at $p<0.05 .1$ : Normal control; 2: Negative control; 3: Positive control; 4: Immunosuppressed $+60 \mathrm{mg} / \mathrm{kg}$ of extract; $\mathbf{5}$ : Immunosuppressed + $90 \mathrm{mg} / \mathrm{kg}$ of extract; 6 : Immunosuppressed $+120 \mathrm{mg} / \mathrm{kg}$ of extract. 


\section{Effect of ASEDS on immunoglobulin A, G and M levels of cyclophosphamide- induced immunosuppression in rats}

The effect of ASEDS on immunoglobulins A, G, and M levels of cyclophosphamide-immunosuppressed rats is shown in Figure 2. The results indicated significant $(p<0.05)$ declines in $\lg A$, IgG, and IgM levels of the negative control relative to the normal control rats. Treatment with graded doses of ASEDS resulted in significant $(p<0.05)$ elevation in $\lg A$, IgM and IgG levels with group 4 rats, treated with $60 \mathrm{mg} / \mathrm{kg}$ b.w. ASEDS registering the highest levels of $\mathrm{IgA}(306.63 \pm 9.23 \mathrm{mg} / \mathrm{dl})$. Group 5 rats, treated with $90 \mathrm{mg} / \mathrm{kg}$ b.w. ASEDS recorded highest levels of IgG $(259.94 \pm 31.68 \mathrm{mg} / \mathrm{dl})$ and $\operatorname{lgM}(1491.16 \pm 26.35 \mathrm{mg} / \mathrm{dl})$ synthesis post-ASEDS treatment.

\section{Effect of ASEDS on the activities of antioxidant enzymes of cyclophosphamide- induced immunosuppression in rats}

Figure 3 shows the effect of ASEDS on the activities of antioxidant enzymes of cyclophosphamideinduced immunosuppression in rats. From the data obtained, we observed significant $(p<0.05)$ declines

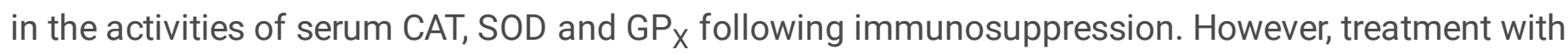
graded doses of ASEDS led to significant $(p<0.05)$ elevations in the activities of these antioxidant enzymes in all test groups when compared to the negative control.

\section{Effect of ASEDS on antioxidant vitamin concentrations of cyclophosphamide- induced immunosuppression in rats}

The effect of ASEDS on antioxidant vitamin concentrations of cyclophosphamide-induced immunosuppression in rats is shown in Figure 4. The results indicated significantly $(P<0.05)$ higher levels of vitamins $\mathrm{A}, \mathrm{C}$ and $\mathrm{E}$ for the negative control following cyclophosphamide pre-treatment. Following administration of ASEDS at doses of 60,90 and $120 \mathrm{mg} / \mathrm{kg}$ b.w., we observed significantly $(\mathrm{P}<$ 0.05 ) higher concentrations of the antioxidant vitamins in all ASEDS-treated groups and the standard control relative to the negative control.

\section{Effect of ASEDS on lipoprotein levels of cyclophosphamide-induced immunosuppression in rats}

Figure 5 presents the effect of ASEDS on lipoprotein levels of cyclophosphamide-induced immunosuppression in rats. Down the groups, the results indicated significant $(p<0.05)$ increases in mean serum LDL and HDL concentrations of Groups 3, 4 and 5 rats when compared to the normal control and negative control. Across the groups, we observed significant $(p<0.05)$ increases in HDL concentration when compared to the corresponding LDL concentration.

\section{Discussion}

The use of plant extracts in traditional medicine continues to provide therapeutic needs of greater percentage of world's population especially in developing countries $[14,15]$. D. stramonium is one of such 
valuable plants with rich therapeutic properties, and has been subjected to myriads of uses and applications due to the presence of secondary metabolites the plant contains [16]. In the present study, the efficacy of ASEDS in modulation the effects of cyclophosphamide-induced immunosuppression in Wistar rats was assessed. According to Farombi et al. [17] several plant-derived compounds have been identified over the years for their immunomodulatory characteristics. As a result, numerous illnesses can be alternatively treated via immunomodulation.

The qualitative phytochemical screening of ASEDS showed the presence of alkaloids, flavonoids, saponins, phenols, glycosides, tannins, terpenoids, steroids and carbohydrates. This agrees largely with the findings of Bano and Adeyemo [18] who reported that the ethanol seed extract of $D$. stramonium contains saponins, flavonoids, terpenoids, steroids, carbohydrates, alkaloids, phenols, tannins, fats and oils. The presence of these phytochemical constituents could be attributed to the geographical location where the plant material was collected, and solvent used for the extraction of the plant materials [19]. Quantitatively, phenols, alkaloids and flavonoids were of the highest concentration, while the least was tannins, steroids and saponins (Table 1). This conforms to the results obtained by Sharma and Sharma [20] in terms of degree of presence of these phytochemicals where they reported high presence of phenols, moderate contents of alkaloids, flavonoids, terpernoids, glycosides and soluble carbohydrates, whereas steroids, saponins and tannins were present in low quantities. Some of these phytochemical constituents have been reported to exhibit stimulatory or inhibitory effect on various components of immune system. The antioxidant role of phenolic and flavonoids can confer anticancer property of the extract on the animals [16]. Tannin was reported by Haslam [21] to stimulate phagocytosis in macrophages and dendritic cells hence the extract could participate in both innate and adaptive immune responses. The relative high presence of alkaloids can confer antitumor activity and enhance immune response [22]. Dash et al. [23] reported that flavonoids increase activity of T-cells, cytokines, interleukins, interferons and macrophages; and are therefore useful in the treatment of several diseases caused by immune dysfunction. According to Jorrossay and Thelen [24], steroids were the most important phytochemical constituent that can reinstate a balance the Th1 and Th2 cells, thus can determine the type of immune response of a system. Carbohydrates could also contribute the immunologic capability of the system [25], by enhancing the recognition of antigens when they presented. Terpenoids were reported to possess ability to modulate critical signaling pathways such as nuclear transcription factor kappa B which helps in prompt synthesis of cytokines [26].

The acute toxicity testing of oral doses of ASEDS in mice revealed that the extract was well tolerated by the rats' up dose of $5000 \mathrm{mg} / \mathrm{kg}$ b.w. (Table 2). This could be due to ability of the animal to metabolize the phyto-constituents via cytochrome $\mathrm{P}_{450}$ transformation to non-lethal level within short period of time hence the extract has a high safety profile. The result disagrees with the findings of Gidado et al. [27] which stated that there was a record of death in rats when extract dose above $100 \mathrm{mg} / \mathrm{kg}$ was administered. This could possibly due to the effect of ethanol used for the plant extraction. However, our findings agree with the findings of Joshua et al. [28] where up to $400 \mathrm{mg} / \mathrm{kg} \mathrm{b.w}$. of the extract was administered without any record of mortality. 
The determination of total leucocyte and differential count are important markers of immune function. In this study, the total leukocyte counts of the ASED-treated groups significantly $(p<0.05)$ increased relative to the negative control (Table 3 ). This effect could be mediated by cytokines such as colony stimulating factor (CSF) 2, a monomeric glycoprotein secreted by macrophages, T-cells, mast cells, natural killer cells, endothelial cells and fibroblasts in response to the presence of xenobiotic. CSF 2 triggers proliferation of leucocytes by activation of hematopoietic stem cells (HSCs). This shows the ability of ASEDS to stimulate leukocytosis. The result is consistent with the findings of Fatoba et al. [29] who stated that bucks treated with aqueous seed extract of $D$. stramonium recorded higher white blood cell counts than the control except at the highest extract dose. There was a significant $(p<0.05)$ decrease in total leucocyte count in the negative control relative to the standard and normal controls, thus validating the efficacy of cyclophosphamide has an immunosuppressive drug. Phosphoramide, an alkylating agent generated by the bio-activation of cyclophosphamide could be responsible for the death of leucocytes as observed in the negative control [30]. Leucocyte count of the standard control was observed to be similar to the that of the normal control which demonstrated efficacy of Levamisole as an immune-booster [31]. This agrees with finding of Undiandeye et al. [32] who reported an increase in leucocyte count following treatment of an immunocompromised goat. The increase in leucocyte counts increases the ability of the host to defend the body against invasion of foreign agents [33].

The lymphocyte counts of Groups 5 and 6 was observed to be significantly $(p<0.05)$ higher when compared to the standard control. It was observed that the effect of ASEDS on lymphocyte counts was dose-dependent (Table 3). This implies that extract has capacity to boost both antibody-dependent and cell-mediated immune responses since lymphocytes play dominate role in immune responses. However, the result is contrary to the findings of [29] who reported increase in lymphocyte counts with decreasing extract dosage. Neutrophil counts increased significantly $(p<0.05)$ in Group 4 compared to the control groups and other test groups; suggesting that the extract can stimulate cell mediated elimination of bacterial pathogens because major phagocytes mobilized during bacterial invasion are neutrophils. As observed, the effect had an inverse dose dependence on other test groups. In other words, low doses of the extract appeared to stimulate more synthesis of neutrophils than high doses. This also disagrees with the findings of Fatoba et al. [29] where high extract doses stimulated increase in the count of neutrophils. Monocyte counts in group 6 increased significantly $(p<0.05)$ compared to all control groups. The extract therefore can enhance cell-mediated immune responses via phagocytosis and antigen presentation. Monocyte can differentiate into active macrophages and dendritic cells [34]. Eosinophils count increased significantly $(p<0.05)$ in Group 5 compared to normal and negative controls respectively. However, the eosinophil counts in the test groups showed significantly $(p<0.05)$ decreased relative to the standard control. This implies that the mechanism by which Levamisole could have stimulated leucocyte differentiation to optimize eosinophil levels. This corroborates the findings of Undiandeye et al. [32] in which eosinophils count of the goat treated with Levamisole increased significantly compared with the normal control.

Immunoglobulins $\mathrm{A}, \mathrm{G}$ and $\mathrm{M}$ are useful markers of immune response. Following cyclophosphamideinduced immunosuppression in rats, we observed significant $(p<0.05)$ decreases in the levels of 
immunoglobulins isotypes (IgA, $\lg G$ and $\lg M)$ of the negative control. Treatment with ASEDS resulted in significant $(p<0.05)$ elevations in IgA, IgG and IgM levels (Fig. 2). This effect could due to the ability of ASEDS to stimulate biosynthesis of interleukin- 6 by T helper 2 cells which enhances B-lymphocytes differentiation into mature plasma cells that secret immunoglobulins. Thus, suggesting the potency of ASEDS to boost humoral immune responses [35]. Also observed was the fact that IgG level was highest among the determined immunoglobulin isotypes implying that ASEDS could enhance antibody dependent cytotoxicity [36].

Aqueous seed extract of $D$. Stramonium $L$. has been previously reported to restore altered antioxidant enzyme activities following cyclophosphamide-induced oxidative stress in rats [28]. In the present study, induction of immunosuppression following pre-treatment with cyclophosphamide led to significant $(\mathrm{p}<$ 0.05) declines in the activities of SOD, CAT and GP (Fig. 3). Administration of ASEDS resulted in significant $(p<0.05)$ elevation of the antioxidant enzymes activities thereby restoring the normal antioxidant balance, thus, suggesting the ability of ASEDS to boost the first line of defense against reactive oxygen species (ROS) generated from the bio-activation of cyclophosphamide. The results disagree with the report of Ogunmoyole et al. [37] who demonstrated that the activities of SOD, CAT and $\mathrm{GP}_{\mathrm{X}}$ were depleted by administration of seed extract of $D$. stramonium $L$. regardless of the solvent used for the extraction. Cyclophosphamide induction also resulted in significant $(p<0.05)$ decrease in the concentrations of vitamins A, C, and E (Fig. 4). This could be accrued to the increased levels of free radicals generated as a result of lipid peroxidation induced by acrolein [28]. The decrease in vitamins $A, C$ and $\mathrm{E}$ concentration is consistent with the work of Joshua et al. [28]. Treatment with graded doses of ASEDS significantly $(p<0.05)$ increased the concentration of antioxidant vitamins, which could scavenge free radicals generated by cyclophosphamide. The increased concentration of the vitamin A following ASEDS treatment shows its ability to enhance innate immunity [38], while vitamins $C$ and $E$ can modulate both cellular and humoral immune responses $[39,40]$.

Cyclophosphamide induction led to reduction in the levels of HDL and LDL of the negative control (Fig. 5). Treatment with ASEDS led to improvements in altered lipid levels. Group 4 rats recorded significant $(p<0.05)$ increase in HDL concentration relative to the negative control and other test groups while Group 6 rats recorded significant reduction in LDL levels. This implies that the integrity of the lipid layer of the immune cell membrane is being varied as cholesterol component is being removed and added respectively by HDL and LDL as known transporters of cholesterol in animal body. Consequently, antigen presentation on the major Histocompatibility (MHC) II of the antigen presenting cells (APCs) and subsequent recognition by appropriate T-cells would be affected because lipid constitute a greater part of MHC, suggesting that ASEDS can modulate both cellular and adaptive responses [41]. It was also observed that HDL-C concentration in each group was significantly higher than the corresponding LDL-C concentration indicating the extract possesses athero-protective capacity. The results corroborate the findings of Ogunmoyole et al. [37] who revealed that the HDL-cholesterol and LDL-cholesterol significantly increased in serum, liver and heart homogenates after administration of aqueous extract of D. stramonium seeds. 


\section{Conclusions}

This study confirmed the immunomodulatory effects of $D$. stramonium $L$. From the results obtained, ASEDS showed potent immunomodulatory effect which could be attributed to the presence of phytochemical constituents such as alkaloids, flavonoids, terpenoids and saponins which played key roles in normalizing altered antioxidant enzyme activities and vitamins levels as well as restoring alterations in lipoproteins levels, and stimulation of leukocytosis and increase in antibody synthesis, thus, serving as a potential candidate immunomodulatory agent.

\section{Materials And Methods}

\section{Materials}

\section{Procurement, identification and authentication of plant material}

Ripe seeds of Datura stramonium L. (Solanaceae) (Fig. 1), were collected from the plant habitat in Anyigba, Dekina Local Government Area, of Kogi State, North Central Nigeria, in July 2018. The plant sample was identified by Prof. M. Adukwu, of the Herbarium of the Department of Botany, Faculty of Agriculture, Kogi State University, Anyigba, Kogi State, Nigeria. The identity and authenticity of the plant was also confirmed with the exact sample deposited in online databases of http://www.theplantlist.org/ and http://www.ipni.org/.

\section{Preparation and processing}

The plant seeds were carefully separated from the whole plant, freed from sand and debris, and air-dried to a constant weight. The dried seeds were pulverized into powdered form, stored in airtight bags prior to aqueous crude extraction.

\section{Study rodents}

A total of twenty (20) adult Swiss mice (24-29 g), and Thirty (30) healthy adult Wistar rats of both sexes (180-200 g), were procured from the Animal House of the Faculty of Basic Medical Sciences, College of Health Sciences, Kogi State University, Anyigba, and were be kept in well ventilated laboratory cages.

They were acclimatized to the laboratory environment for a period of seven days under standard environmental conditions, with a $12 \mathrm{~h}$ light/dark cycle. The animals were fed with standard feed pellets and drinking water ad libitum, and were accorded humane care throughout the period of the experiment, in line with the regulations and ethical approval of the Ethics and Biosafety Committee of the Faculty of Biological Sciences, University of Nigeria, with Reference No. UNN/FBS/EC/1046, and in accordance with the International ethical guidelines for care and use of laboratory animals [42].

\section{Drugs, chemicals and reagents}


All chemicals and reagents used for the conduct of this study were of analytical grade. Drugs used were purchased from reputable pharmaceutical outlets in Lokoja, Kogi State, Nigeria. Freshly prepared phosphate buffer at pH 7.4 and normal saline were used for the study. Distilled and deionized water were obtained from the National Centre for Energy Research and Development (NCERD), University of Nigeria, Nsukka. Hydrogen peroxide (Interstate Chemical Co. Hermitage, PA), Bovine serum albumin (BioClot $\mathrm{GmbH}$ ), Phosphotungstic acid (CDH Fine Chemicals, India). Orthophosphoric acid (Prime Chemicals, Gujarat, India). Ascorbic acid, oxalic acid, batophenanthroline, sodium hydroxide, iron (III) chloride, petroleum ether and ethyl acetate (Sigma Aldrich, St. Louis, MO, U.S.A.). Chloroform, methanol, ethanol, sulfuric acid, and hydrochloric acid (British Drug House, England). Fehling's solutions A and B (Sisco Research Lab., India). Xylene (Shantou, Guangdong, China). Cyclophosphamide was purchased from Cadila Healthcare Limited, Marketed by Zydus Oncosciences, Baxter Oncology, Frankfurt Germany. Levamisole (47.3 mg) was purchased from Ecomed Pharma Limited, Ogun State Nigeria. Glutathione peroxidase $\left(\mathrm{GP}_{\mathrm{X}}\right)$ activity assay kit was obtained 'Ready to use' from Cayman Chemical, Ann Arbor, Michigan, USA. The kits for High-density lipoprotein (HDL) and Low-density lipoprotein (LDL) were products of Prestige diagnostics, Geigorim Co Antrim, United Kingdom. Catalase (CAT) and superoxide dismutase (SOD) assay reagent kits were procured from Randox Laboratories Ltd., United Kingdom. Immunoglobulins A, G, and M 'Ready to use' assay kits were procured from Weiner's Laboratory, California, U.S.A.

\section{Methods}

\section{Crude plant extraction}

Crude plant extraction was carried out according to the method of Sofowara [43] with slight modifications. A known weight, $257.6 \mathrm{~g}$ of the powdered seeds were soaked in $2567 \mathrm{~mL}$ liters of distilled water and allowed to stand for $48 \mathrm{~h}$ at room temperature. The mixture was then filtered using a vacuum pump, and the filtrate was lyophilized to yield $20.35 \mathrm{~g}$ of the aqueous seed extract of $D$. Stramonium L. (ASEDS). The percentage yield of ASEDS was determined using the formula given below.

$$
\text { Percentage yield }=\frac{\text { weight of extract }(\mathrm{g})}{\text { weight of powdered seed }(\mathrm{g})} \times \frac{100}{1}
$$

\section{Phytochemical analyses}

The phytochemical screening of ASEDS was carried out using the methods of Harborne [44], and Pearson [45].

\section{Determination of $\mathrm{LD}_{50}$ of ASEDS}

The acute toxicity was conducted in accordance to the method of Lorke [46]. The study was conducted in two phases using a total of twenty (20) male Swiss mice of (24-29 g). In the first phase, 9 mice are divided into three groups of 3 mice each. Groups 1, 2 and 3 animals were orally administered 10, 100 and 
$1000 \mathrm{mg} / \mathrm{kg}$ body weight (b.w.) of ASEDS respectively; while a mouse used as the control was as only administered physiological saline. In the second phase, 1600, 2900 and $5000 \mathrm{mg} / \mathrm{kg} \mathrm{b}$.w. of ASEDS were administered orally to the remaining nine mice respectively. A mouse served as the control. The treated mice were observed for $24 \mathrm{~h}$ for signs of acute intoxication as well as mortality.

\section{Induction of immunosuppression}

Immunosuppression in Wistar rats was induced according to the protocol of Joshua et al. [28]. Accordingly, $10 \mathrm{mg} / \mathrm{kg}$ b.w. of Cyclophosphamide was administered orally for 27 days to induce immunosuppression in designated rat groups.

\section{Experimental design}

The experimental design of Kyakulaga et al. [47] as modified, was adopted. Thirty (30) rats were divided into six groups of 5 rats each. Group 1 served as normal control and received $1 \mathrm{~mL} / \mathrm{kg}$ b.w. distilled water throughout the duration of the experiment. Group 2 served as negative control and was pretreated with 10 $\mathrm{mg} / \mathrm{kg}$ b.w. Cyclophosphamide orally for 27 days followed by $1 \mathrm{~mL} / \mathrm{kg}$ b.w. distilled water given orally for 28 days' post treatment. Group 3 served as standard control, and were pretreated with $10 \mathrm{mg} / \mathrm{kg}$ b.w. Cyclophosphamide followed by $5 \mathrm{mg} / \mathrm{kg}$ b.w. of Levamisole [32]. Groups 4, 5 and 6 made up the ASEDS test groups. Rats in these groups were orally pre-treated with $10 \mathrm{mg} / \mathrm{kg}$ b.w. Cyclophosphamide for 27 days, followed by 60,90 , and $120 \mathrm{mg} / \mathrm{kg}$ b.w. of ASEDS respectively, administered orally for 28 days. Thereafter, the rats were fasted overnight, and euthanized by cervical dislocation prior to sacrifice on day 29 [48]. Fresh blood samples were collected via cardiac puncture and emptied into neatly labeled plain tubes. Serum was obtained by centrifugation at $3000 \mathrm{rpm}$ for 10 minutes, and stored in the refrigerator for subsequent biochemical analyses.

\section{Determination of biochemical indices}

Total leucocytes and differential cell counts were determined using an automated hematology analyzer (URIT-330) based on Coulter's method as described by Robinson [49] Serum catalase activity was assayed according to the method of Sinha [50]. Superoxide dismutase activity was assayed by the inhibiting of auto-oxidation of epinephrine, using the protocol of Pajovic et al. [51]. Glutathione peroxidase activity was assayed according to the method of Paglia and Valentine [52] as described by Ekpo et al. [48]. The concentration of serum Vitamin A was determined by the method of Rutkowski et al. [53]. Serum vitamin C concentration was determined by the method of Rutkowski et al. [54], while serum vitamin E concentration was determined by the method of Rutkowski et al. [55]. High density lipoprotein concentration in serum was determined according to the method described by Kameswara et al. [56], while Low-density lipoprotein concentration was determined by the method of Arsman et al. [57], using an Auto-analyzer (URIT-810).

\section{Determination of serum immunoglobulin $A, G$ and $M$ concentrations}


Serum immunoglobulin $A, G$, and $M$ concentrations were determined according to the method of Pressac et al. [58]. The method is based on the principle that immunoglobulin reacts with specific antigen to generate insoluble immune complexes. The turbidity of the complexes is directly proportional to the immunoglobulin concentration in the sample which can be measured using a spectrophotometer. Briefly, a calibration curve was drawn from serial dilutions of the calibrator protein in saline solution at 1:10, $1: 20,1: 40,1: 80$, and 1:160 using saline solution as zero point. $40 \mu \mathrm{L}$ of diluted calibrator protein was mixed with $900 \mu \mathrm{L}$ of Reagent A (buffered saline solution). The mixture was homogenized and the absorbance of the dilutions were measured at $340 \mathrm{~nm}$ as $\mathrm{OD}_{1}$, after calibrating the instrument to zero with distilled water as blank. An aliquot of $160 \mu \mathrm{L}$ of Reagent B (antibody monospecific anti-lgA, IgG, or $\lg M$ ) was then added to the mixture and incubated at room temperature for $30 \mathrm{~min}$. The absorbance of

the reacting mixture $\left(O D_{2}\right)$ was measured against the blank. The difference in absorbance $\left(O D_{2}-O D_{1}\right)$ for each calibrator protein dilution, including the zero point was calculated. A plot of calibrator protein concentrations in $\mathrm{mg} / \mathrm{dl}$ against the differences in absorbance was plotted. For the sample, an aliquot of $10 \mu \mathrm{L}$ was mixed with $100 \mu \mathrm{L}$ of saline solution to achieve a 1:10 dilution. Thereafter, $40 \mu \mathrm{L}$ of the diluted sample was mixed with $900 \mu \mathrm{L}$ of Reagent $\mathrm{A}$. The mixture was homogenized and the absorbance of the dilution was measured at $340 \mathrm{~nm}$ as $\mathrm{OD}_{1}$ using distilled water as blank. Thereafter, $160 \mu \mathrm{L}$ of Reagent $\mathrm{B}$ was then added to the mixture and incubated at room temperature for $30 \mathrm{~min}$. The absorbance of the reaction mixture $\left(\mathrm{OD}_{2}\right)$ was measured against the blank. The differences in absorbance was determined, and the concentration of immunoglobulin $\mathrm{A}, \mathrm{G}$, and $\mathrm{M}$ respectively, in the serum $(\mathrm{mg} / \mathrm{dl})$ was determined from the standard calibration plot.

\section{Statistical analyses}

The data obtained from the study were analyzed using IBM Statistical Product and Service Solutions (SPSS) version 21.0 (Chicago, IL), and GraphPad Prism version 7.0. Significant differences in the means were established by the one-way analysis of variance (ANOVA), post hoc multiple comparison, Duncan homogenous subset, and Turkey multiple comparison test. Student's t-test was used to compare mean body weights in the acute toxicity study. The results were presented as mean \pm standard deviation of replicate measurements. Mean values with $p \leq 0.05$ were significantly different.

\section{Abbreviations}

ASEDS: Aqueous seed extract of Datura stramonium; HDL: High-density lipoprotein; LDL: Low-density lipoprotein; CAT: Catalase; SOD: Superoxide dismutase; Glutathione peroxidase GPx; CSF: Colony stimulating factor; WHO: World Health Organization.

\section{Declarations}

Acknowledgements 
Authors are thankful to Anne Sylvanus Obot of the Department of Chemistry, University of Uyo, Uyo, Nigeria, for proofreading the manuscript.

\section{Author contributions}

All authors made significant contributions to the conceptualization and design of the study.

P. E. Joshua: Conceptualized and designed the work; Analyzed and interpreted the data; Supervised the work.

J. Yahaya and 0. S. Adeniyi: Conceptualized and designed the work; Reviewed relevant literatures and methodology; Performed laboratory experiments.

D. E. Ekpo: Analyzed and interpreted the data; Performed laboratory experiments; Wrote the draft and final versions of the manuscript, and coordinated the peer review process.

J.O. Ogidigo and A.S. Odiba: Reviewed relevant literatures and methodology; Analyzed and interpreted the data; Wrote the draft manuscript.

R. O. Asomadu and S. A. Oka: Reviewed relevant literatures and methodology; Analyzed and interpreted the data.

All authors read and approved the manuscript.

Funding: No funding was received for the conduct of this study.

Availability of data and materials: The datasets used and/or analysed during the current study are available from the corresponding author on reasonable request.

Ethical approval: All procedures performed involving the use of experimental animals in this study were conducted in line with the regulations and ethical approval of the Ethics and Biosafety Committee of the Faculty of Biological Sciences, University of Nigeria, with Reference No. UNN/FBS/EC/1046, and in accordance with the International Guidelines for Handling of Laboratory Animals [59].

Consent to participate: Not applicable

Consent for publication: Not applicable

Competing interest: The authors have no conflict of interest to declare that are relevant to the content of this article.

\section{Author details}

a Department of Biochemistry, Faculty of Biological Sciences, University of Nigeria, 410001, Nsukka, Enugu State, Nigeria. 
${ }^{b}$ Department of Human Physiology, Faculty of Basic Medical Sciences, Colleges of Health Sciences, Kogi State University, P.M.B. 1008, Anyigba, Kogi State, Nigeria.

${ }^{c}$ Bioresources Development Centre, National Biotechnology Development Agency (NABDA), Federal Capital Territory, Abuja, Nigeria.

d Department of Molecular Genetics and Biotechnology, Faculty of Biological Sciences, University of Nigeria, 410001, Nsukka, Enugu State, Nigeria.

${ }^{\mathrm{e}}$ Department of Biochemistry, College of Life Science and Technology, Guangxi University, 530007, Nanning, People's Republic of China.

${ }^{f}$ National Engineering Research Centre for Non-Food Biorefinery, Guangxi Academy of Sciences, 530007, Nanning, People's Republic of China.

9 Department of Medical Biochemistry, Faculty of Basic Medical Sciences, Colleges of Health Sciences, Kogi State University, P.M.B. 1008, Anyigba, Kogi State, Nigeria.

${ }^{\mathrm{h}}$ Department of Physiology, Faculty of Basic \& Allied Medical Sciences, Benue State University, Benue State, Nigeria.

\section{References}

1. Odetola O, Ananthanarayanan V. Gastrointestinal presentations of common variable immunodeficiency: Hiding in plain sight. Arc Pathol Lab Med. 2019;143:525-30.

2. Hutchinoson JA, Geissler EK. Now or never? The case for cell-based immunosuppression in kidney transplantation. Kidney Int. 2015;87(6):1116-24.

3. Fuehner T, Benden C, Gottlieb J. Initiating immunosuppression and managing rejection. Intensive Care Med. 2019;45:388-90.

4. Wlodarczynska M, Ograczyk E, Kowalewicz M, Druszcynska M. Effect of cyclophosphamide treatment of central and effector memory T cells in mice. Int J Toxicol. 2018;37(3):1091-11.

5. Heinhuis KM, Ros W, Kok M, Steeghs N, Beijnen JH, Schellens JHM. Enhancing anti-tumour response by combining immune checkpoint inhibitors with chemotherapy in solid tumours. Ann Oncol. 2019;30(2):219-35.

6. Alhmann H, Hempel G. The effect of cyclophosphamide on the immune system: implications for clinical therapy. Cancer Chemother Pharmacol. 2016;78(4):661-71.

7. Parveen A, Vijula K, Avinash KV, Ravishankar M, Leeladhar DV. Medicinal values of Datura. A specific review. Int J Green Pharm. 2016;10(2):1-77.

8. Arowora KA, Imo C, Ezeonu CS, Muhammed ZI. Effects of ethanolic extracts of Datura metel on blood lipid profile of male albino rats. Int J Sci Rep. 2016;2(10):248-52 
9. Chavhan SA, Kadam SD, Shinde SA, Sapkal PN. Pharmacognostic review on Datura. Int J Pharmacogn Chin Med. 2018;2(4):145-9.

10. Dewitt JC, Blossom SJ, Schaider LA. Exposure to perfluoroalkyl and polyfluoroalkyl substances lead to immunotoxicity: epidemiological and toxicological evidence. J Expo Sci Eviron Epidemiol. 2019;29(2):140-8.

11. World Health Organization [WHO]. Communicable disease surveillance and response: WHO Global strategy for containment of antimicrobial resistance [Accessed: December 20, 2013]. Available online at: http://www.who.int/crs/resources/publications/drugresist/en/EGlobal.Strat.pdf. (2013).

12. Abood WN. Immunomodulatory and natural immunomodulators. J Allerg Inflamm. 2017;2:99-101.

13. Jantan I, Ahmad W, Bukharu S. Plant-derived immunomodulators: an insight on their pre-clinical evaluation and clinical trials. Front Plant Sci. 2018;9:1178-94.

14. Cordell GA. Plants in Drug Discovery-Creating a New Vision. In: Tan, B. K., Bay, B. H. and Zhu, Y. Z. (Eds). Novel Compounds from Natural Products in the New Millennium Potential and Challenges, National University of Singapore: World Scientific Publishing, Singapore, 2004; pp. 1-7.

15. Abo KA, Fred J, Jaiyesimi AE. Ethnobotanical studies of medicinal plants used in the management of diabetes mellitus in South Western Nigeria. J Ethnopharmacol. 2007;115(3):67-71.

16. Soni P, Siddiqui AA, Dwivedi J, Soni V. Pharmacological properties of Datura stramonium L. as a potential medicinal tree. Asian Pac J Trop Biomed. 2012;2(12):1002-08.

17. Farombi E, Nwankwo J, Emerole G. Effect of methanolic extract of browned yam flour diet on 7, 12dimethylbenzanthracene (DMBA) and 3-methylcholanthrene (3-Mc) induced toxicity in the rat. Proc Fed Afr Soc Biochem Mol Biol. 1998;1:5-10.

18. Bano A, Adeyemo S. Phytochemical screening and antimicrobial assessment of Abutilon mauritianum, Bacopa monnifera and Datura stramonium. Int J Med Pharmacol. 2006;18(1):39-44

19. Adesina GO, Okeke CE, Osuagwu NO, Ehinmidu JO. Preliminary in-vitro antibacterial activities of ethanolic extracts of Ficussycomorus Linn and Ficusplatyphylla Del. (Moraceae). Afr J Microbiol Res. 2010;4(8):598-01.

20. Sharma MC, Sharma S. Phytochemical, preliminary pharmacognostical and antimicrobial activity of combined crude aqueous extracts. Int. J Microbiol Res. 2013;1(3):166-70.

21. Haslam E. Natural polyphenols (vegetable tannis) as drugs; possible mode of action. J Nat Prod. 1996;59:205-15.

22. Okwu DE, Okwu ME. Chemical compositions of Spondias mormbia plant parts. J Sustain Agric Environ. 2004;6:140-7.

23. Dash S, Nath LK, Bhise S, Kar P, Bhattacharya S. Stimulation of immune functional activity by the alcoholic root extract of Heracleum napalense D. Don. Indian J Pharmacol. 2006;38(5):336-40.

24. Jorrossay D, Thelen M. Immune response: steroids drive dendritic cells. Nat Immunol. 2013;14:4246. 
25. Avci FX, Li X, Tsuji M, Kasper DL. Carbohydrates and T-cells: a sweet twosome. Semin Immunol. 2013;25:146-51.

26. De Las HB, Hortelano S. Molecular basis of the anti-inflammatory effects of terpernoids. Inflamm Allergy Drug Targets. 2009;8(1):28-39.

27. Gidado A, Zainab A, Hadiza MU, Serah DP, Anas, HY, Milala MA. Toxicity studies of ethanol extract of the leaves of Datura stramonium in rats. Afr J Biotechnol. 2007;6(8):1012-15.

28. Joshua PE, Asomadu RO, Eze CS, Nnamani IV, Kingsley CO, Nweje-Anyalow CP, et al. Effect Datura stramonium on cyclophosphamide-induced oxidative stress in albino rats. Int J Pharmacol, 2019;15(8):926-32.

29. Fatoba TA, Adeloye AA, Soladoye AO. Effect of Datura stramonium seed extract on hematological parameters of West Africa Dwarf (WAD) bucks. Eur J Exp Biol. 2013;3(4):1-6.

30. Chighizola C, Ong VH, Christopher PD. Cyclophosphamide as a disease modifying therapy for sclerodema. Int J Clin Rheumatol. 2011;6(2):219-30.

31. Mohri M, Seifis HA, Zmani SH. Effects of oral administration of levamisole on non-specific immunity, serum proteins and health in normal colostrum-fed neonatal dairy calves. Comp Clin Pathol. 2005;13(3):132-6.

32. Undiandeye UT, Oderinde BS, El-Yuguda A, Baba SS. Immunostimulatory effect of levamisole on the immune response of goats to peste des petits ruminants (PPR) vaccination. World $J$ Vaccines. 2014;4:88-95.

33. Stock W, Hoffman R. White blood cells 1: non-malignant disorders. Lancet. 2006;355:1351-7.

34. Auffray C, Fogg D, Garfar M, Elain G, Join-Lambert O, Kayal S, et al. Monitoring of blood vessel and tissues by a population of monocytes with patrolling behaviour. Science. 2007;317(5838):666-70.

35. Degn SE, Theil S. Humoral pattern recognition and the implement system. Scand J Immunol. 2013;78(2):181-93.

36. Racine R, McLaughlin M, Jones DD. IgM production by bone marrow plasmablasts contributes to long-term protection against intracellular bacterial infection. J. Immunol. 2011;186(2):1011-21.

37. Ogunmoyole T, Adeyeye RI, Olatilu BO, Akande, AO, Agunbiade OJ. Multiple organ toxicity of Datura stramonium seed extracts. Toxicol Rep. 2019;6:983-9.

38. Stephensen CB. Vitamin A, infection, and immune functions. Ann Rev Nutr. 2001;21:167-92.

39. Moriguchi S, Murage M. Vitamin E and immunity: a review. Vitam Horm. 2000;59:305-36.

40. Padayatty SJ, Katz A, Wang Y, Eck P, Kwon O, Lee JH, et al. Vitamin C as an antioxidant: evaluation of its role in disease prevention. J Am Col Nutr. 2003;22(1):182-95.

41. Zhou X, Hansson GK. Immunomodulation and vaccination for atherosclerosis. Opin Biol Ther. 2004;4:599-12.

42. National Academy of Sciences [NAS]. Guide for the care and use of laboratory animals, 8th ed. Institute for Laboratory Animal Research, Division on Earth and Life Studies. Washington (DC): National Academy of Sciences. 2011. 
43. Sofowara A. Medicinal plants and traditional medicine in Africa. John Wiley and Sons Ltd., Hoboken. 1982.

44. Harborne J. Phytochemical Methods: A Guide to Modern Technology of Plant Analysis, $3^{\text {rd }}$ edn, Chapman and Hall, New York,1998; pp.88-185.

45. Pearson D. Chemical Analysis of Food, $7^{\text {th }}$ Edn, Church-hill Livingston, Edinburgh, 1976; pp. 10-5.

46. Lorke, D., 1983. A new approach to practical acute toxicity testing. Arch Toxicol. 1983;54(4):275-87. https://doi.org/10.1007/BF01234480

47. Kyakulaga AH, Ogwang PE, Obua C, Nakabonge G, Mwavu EN. Immunomodulatory effects of aqueous extracts of Auricularia $s p$ and Pleurotus $s p$ mushrooms in cyclophosphamideimmunosuppressed Wistar rats. J Pharm Res Int. 2013;3(4):662-70.

48. Ekpo DE, Joshua PE, Odiba AS, Nwodo OFC. Flavonoid-rich fraction of Lasianthera africana leaves alleviates hepatotoxicity induced by carbon tetrachloride in Wistar rats. Drug Chem Toxicol. 2021. https://doi.org/10.108001480545.2021.1892957

49. Robinson JP. Wallace H. Coulter: Decades of Invention and Discovery. Cytometry. 2013;1:83-8.

50. Sinha AK. Colorimetric assay of catalase. Anal Biochem. 1972;4(2):389-94.

51. Pajovic S, Pejic S, Kasaporic J, Radojac M, Borojevic N. Role of superoxide dismutase in industrialization of breast cancer radiation therapy protocol. Arc Oncol. 2003;11(3):191-2.

52. Paglia, D.E. and Valentine, W.N. Studies on the quantitative and qualitative characterization of erythrocyte glutathione peroxidase. J Lab Clin Med. 1967;70(1):158-69.

53. Rutkowski M, Grzegorczyk K, Kędziora J. Laboratory convenient modification of Bessey method for vitamin A determination in blood plasma. J Physiol Pharmacol. 2006;57:221-6.

54. Rutkowski M, Grzegorczyk K, Greger J. Adaptation of the phosphotungstate method to determine reduced and oxidized vitamin $C$ in blood plasma. Zeitschr Naturforsch. 2004;59:762-7.

55. Rutkowski M, Grzegorczyk K, Paradowski MT. Colorimetric determination of total vitamin $\mathrm{E}$ concentration in plasma - own modification of Tsen's method. Diagn Lab. 2005;41:375-85.

56. Kameswara RB, Kesavulu MM, Giri CH. Anti-diabetic and hypolipidemic effects of Momordica cymbalania hook fruit powder in alloxan-induced diabetic rats. J Ethnopharmacol. 1999;67:103-9.

57. Arsman G, Jabs HU, Kuhnert U, Nolte W, Schriewer H. LDL-cholesterol, polyvinyl sulphate method. Clin Chem Acta.1884;140:77-83.

58. Pressac M, Huisse F, Aymard P. Adaptation of IgG, IgA and IgM determination on the Ismat: a turbidemetric method. Ann J Clin Biol. 1983;41(5):315-317.

59. Derrell C. Guide for care and use of laboratory animals. Institute of Laboratory Animal Resources. National Academy Press, Washington DC. 1996.

\section{Figures}



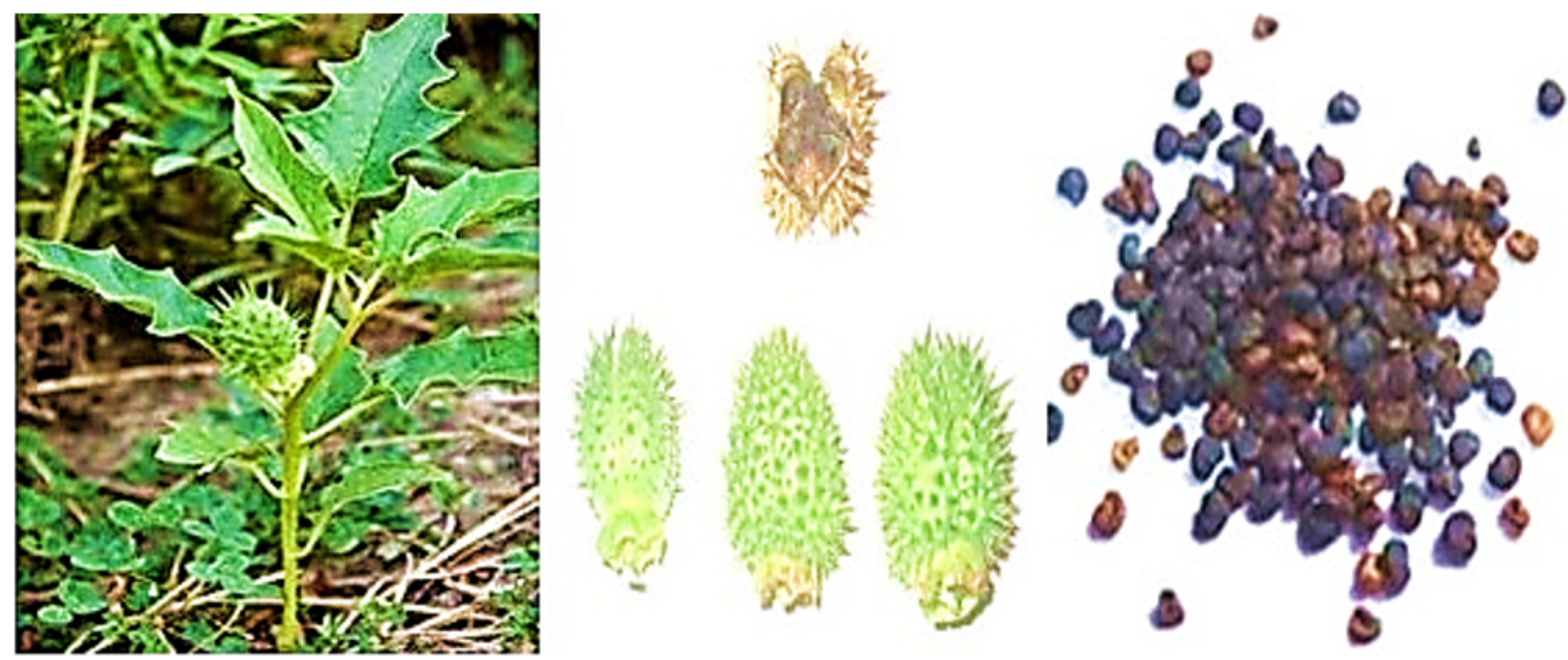

Figure 1

Datura stramonium L. plant, fruits and seeds

Normal control (distilled water)

Negative control (IMSD)

IMSD + $5 \mathrm{mg} / \mathrm{kg}$ b.w. Levamisole

IMSD + $60 \mathrm{mg} / \mathrm{kg}$ b.w. ASEDS

IMSD + $90 \mathrm{mg} / \mathrm{kg}$ b.w. ASEDS

IMSD + $120 \mathrm{mg} / \mathrm{kg}$ b.w. AESDS

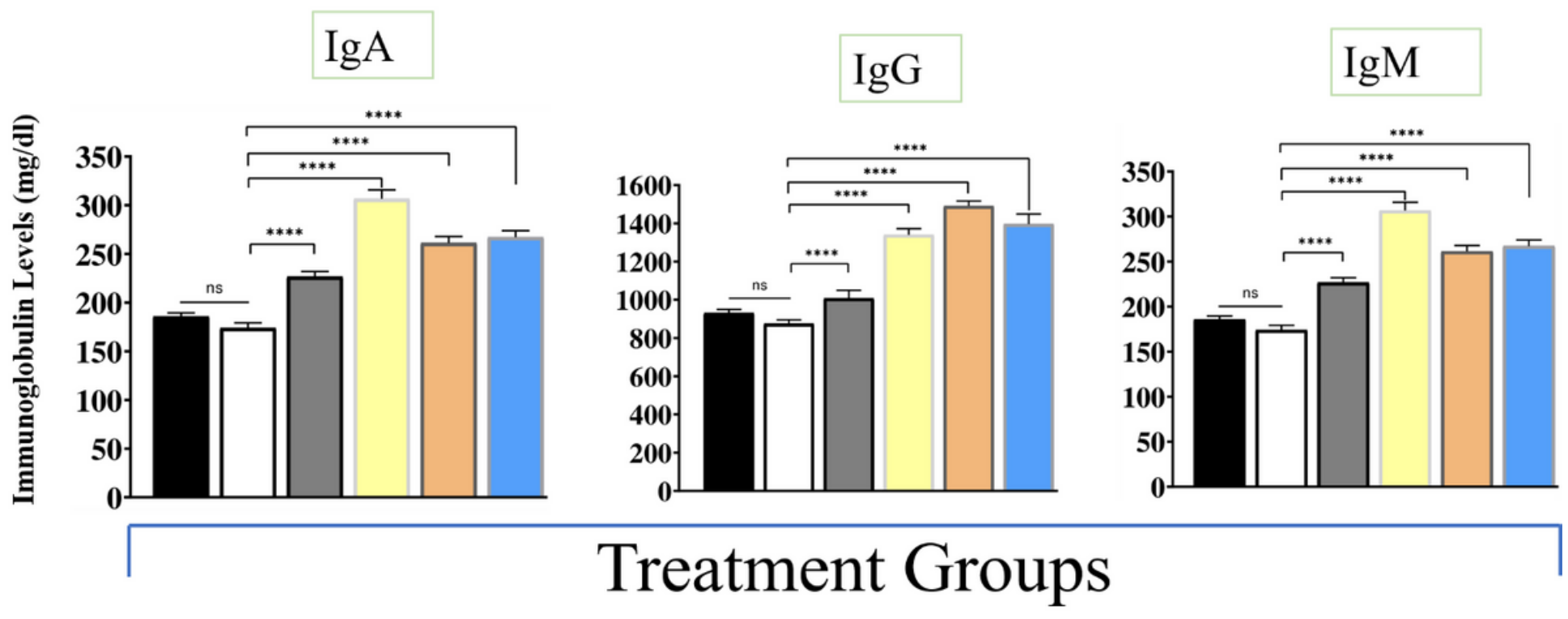

Figure 2

Effect of ASEDS on immunoglobulin A, G and M levels of cyclophosphamide-induced immunosuppression in rats. 


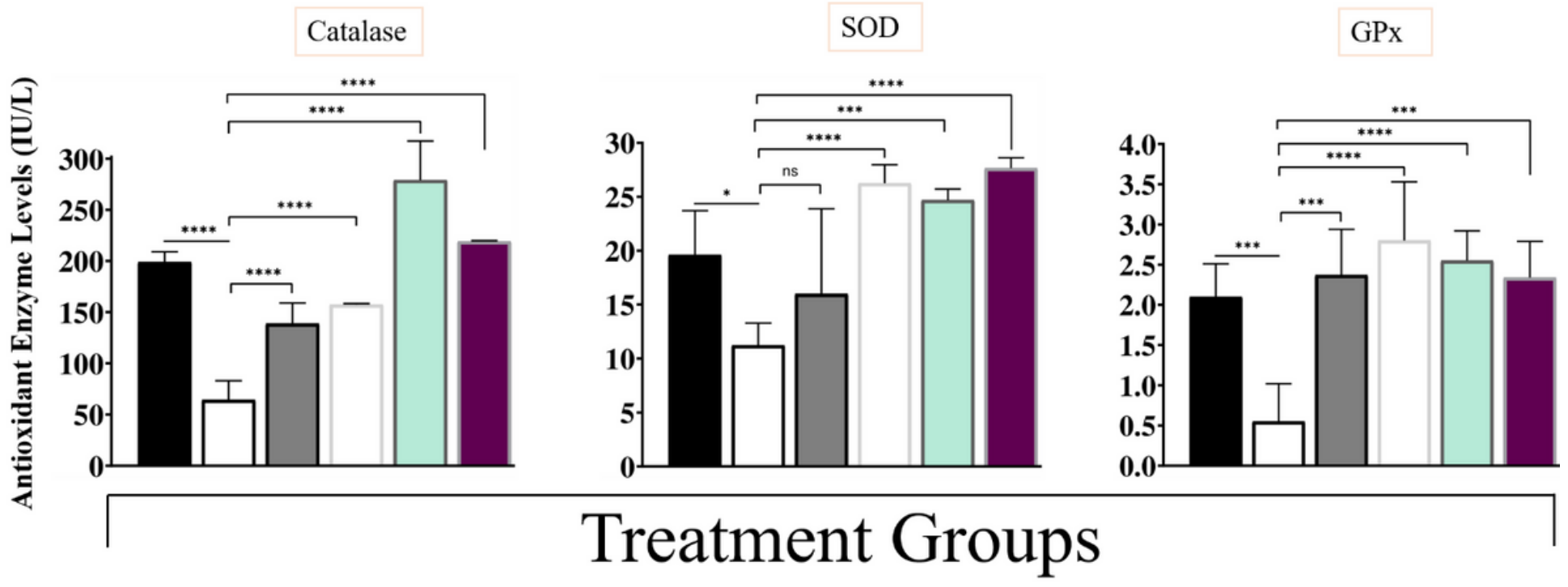

Figure 3

Effect of ASEDS on the activities of antioxidant enzymes of cyclophosphamide-induced immunosuppression in rats.

Normal control (distilled water)

Negative control (IMSD)

IMSD + $5 \mathrm{mg} / \mathrm{kg}$ b.w. Levamisole

IMSD + $60 \mathrm{mg} / \mathrm{kg}$ b.w. ASEDS

IMSD + 90 mg/kg b.w. ASEDS

IMSD + 120 mg/kg b.w. AESDS

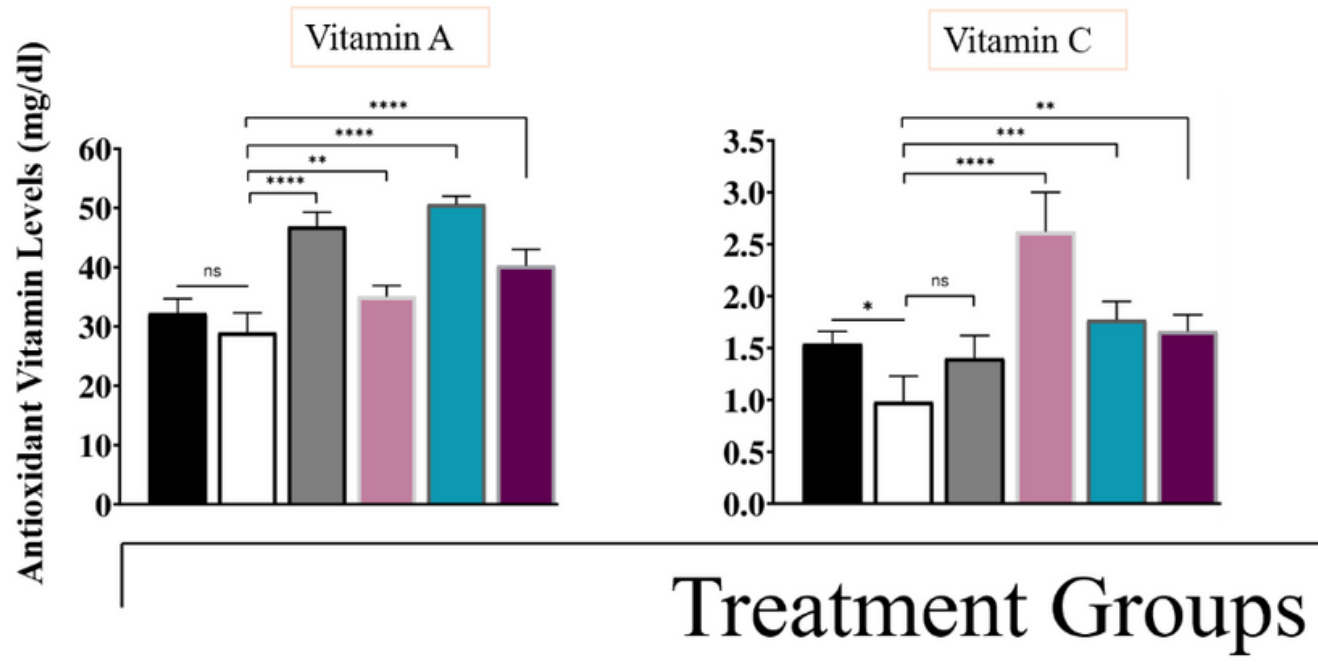

Vitamin E

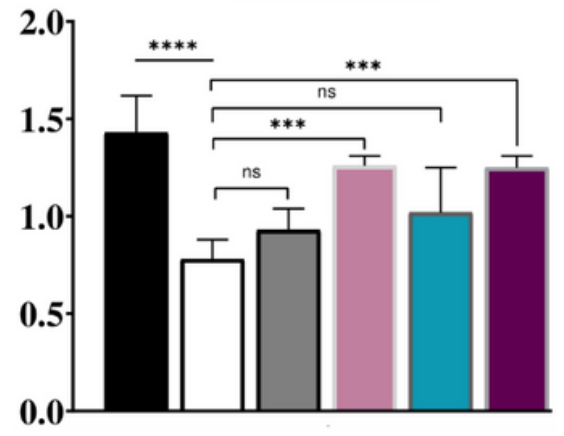

Figure 4 
Effect of ASEDS on antioxidant vitamin concentrations of cyclophosphamide induced immunosuppression in rats.

Normal control (distilled water)

$\square$ Negative control (IMSD)

IMSD + 5 mg/kg b.w. Levamisole

$\infty$ IMSD + 60 mg/kg b.w. ASEDS

( IMSD + $90 \mathrm{mg} / \mathrm{kg}$ b.w. ASEDS

IMSD + $120 \mathrm{mg} / \mathrm{kg}$ b.w. AESDS

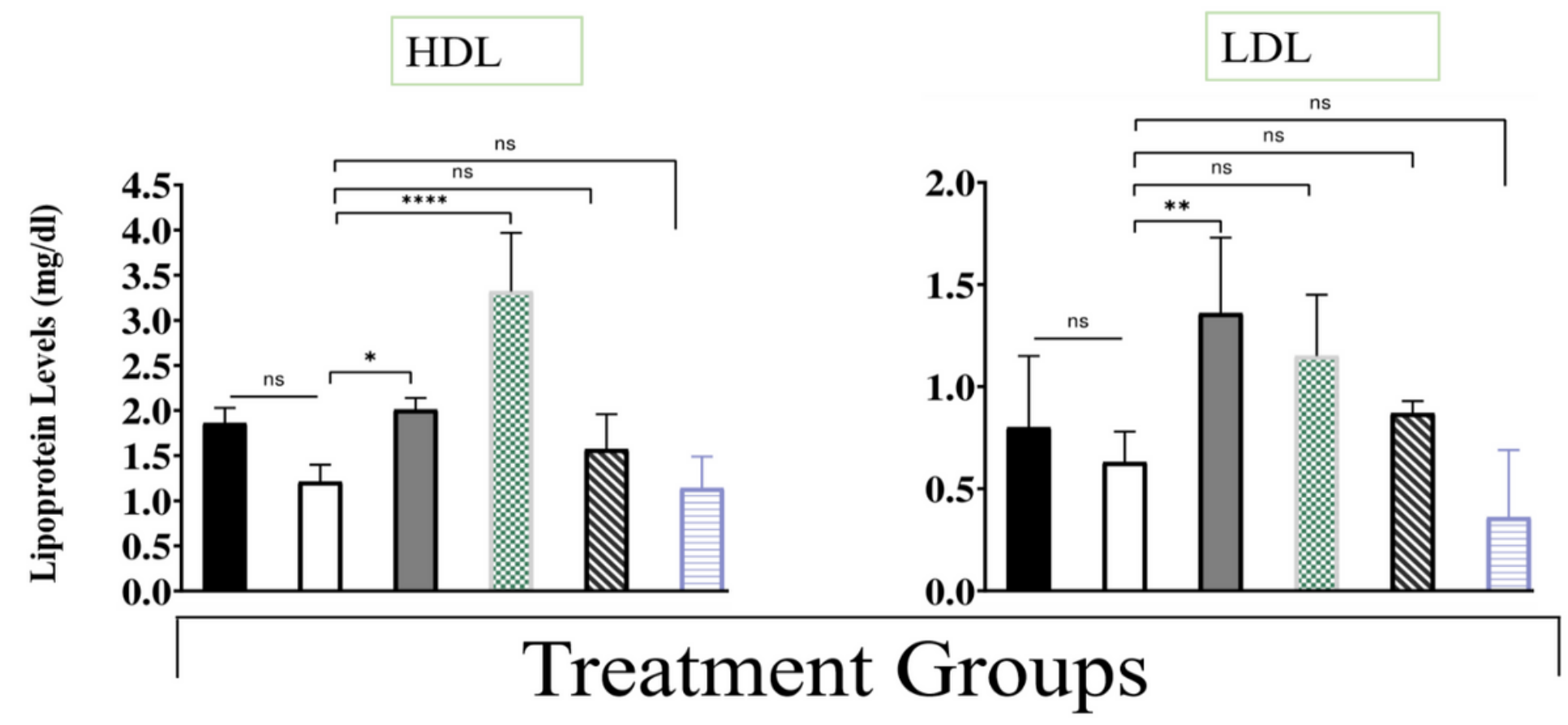

Figure 5

Effect of ASEDS on lipoprotein levels of cyclophosphamide-induced immunosuppression in rats

\section{Supplementary Files}

This is a list of supplementary files associated with this preprint. Click to download.

- SupplementaryData.docx 